\title{
OPERASIONAL PRODUK INVESTASI EMAS PADA PEGADAIAN SYARIAH DITINJAU DARI PRINSIP EKONOMI ISLAM
}

\author{
S. Purnamasari ${ }^{1}$, Kurniaty ${ }^{2}$, Purnama Rozak ${ }^{3}$ \\ Ekonomi Syariah, Universitas Islam Kalimantan MAB \\ Ekonomi, Universitas Islam Kalimantan MAB \\ Tarbiyah, STIT Pemalang \\ Email: s.purnamasari1980@gmail.com \\ Kurniaty60_uniska@yahoo.com \\ rozakpurnomo@yahoo.com
}

\begin{abstract}
Abstrak
Investasi merupakan salah satu instrumen penting sebagai jaminan masa depan bagi setiap manusia. Lembaga Pegadaian yang kini berkembang pesat dapat menjadi alternatif bagi nasabah yang ingin berinvestasi. Tujuan penelitian ini adalah untuk mengetahui oprasional Investasi Emas di Pegadaian Syariah terkait tujuan, mekanisme, persyaratan nasabah pemohon, jangka waktu, jaminan, keuntungan dan biaya yang dibebankan kepada nasabah pemohon ditinjau dari prinsip-prinsip investasi emas ekonomi syariah berupa fatwa dan pandangan muamalah fiqh. Penelitian ini menggunakan penelitian lapangan dengan mengunjungi objek penelitian secara langsung untuk memperoleh berkas-berkas yang dibutuhkan melalui wawancara, observasi terhadap operasionalisasi Investasi Emas. Sedangkan analisis yang digunakan untuk mengolah data yang telah diperoleh adalah analisis deskriptif untuk menghasilkan hasil. Hasil dari penelitian ini adalah Investasi Emas untuk membeli skema KPR di Pegadaian Syariah atau Pegadaian Syariah belum sepenuhnya sesuai dengan beberapa Fatwa Fiqh dan Prinsip Ekonomi Islam, yaitu kejelasan barang dalam akad, yang mengandung nilai investasi spekulatif. Kajian ini berkontribusi terhadap kajian produk investasi dipandang dari prinsip ekonomi Islam.

Kata kunci: Investasi Emas, Beli Gadai, Pegadaian Syariah/Syariah,.
\end{abstract}

\begin{abstract}
Investment is one of the important instruments as collateral in the future for every human being. Pawnshop institutions are now growing rapidly can be an alternative for customers whowish to invest. The purpose of this study was to determine oprasional Gold Investment in Islamic pawnshop-related goals, mechanisms,

${ }^{1}$ Penulis adalah Dosen Fakultas Studi Islam Uniska Muhammad Arsyad al-Banjary Banjarmasin, dan Dosen Tidak Tetap Fakultas Syariah dan Ekonomi Islam IAIN Antasari Banjarmasin

2 Penulis adalah Dosen Fakultas Studi Islam Uniska Muhammad Arsyad al-Banjary Banjarmasin, dan Dosen Tidak Tetap Fakultas Syariah dan Ekonomi Islam IAIN Antasari Banjarmasin

3 Penulis adalah Dosen Fakultas Studi Islam Uniska Muhammad Arsyad al-Banjary Banjarmasin, dan Dosen Tidak Tetap Fakultas Syariah dan Ekonomi Islam IAIN Antasari Banjarmasin
\end{abstract}

Al Qalam: Jurnal Ilmiah Keagamaan dan Kemasyarakatan Vol. 16, No. 2

$$
\text { Maret - April } 2022
$$


S. Purnamasari, Kurniaty, Purnama Rozak : Operasional Produk Investasi Emas Pada Pegadaian Syariah Ditinjau Dari Prinsip Ekonomi Islam

customer requirements the applicant, term, collateral, benefits and fees charged to customers in terms of the applicant's gold investment principles of Islamic economy in the form of fatwas and outlook muamalah fiqh. This study uses field research by visiting the direct object of study to obtain the required files through interviews, observation on operationality of Gold Investment. While the analysis is used to process the data that has been obtained is descriptive analysis to produce results. Results from this study is that Gold Investment to buy mortgage scheme on Islamic Pawnshop or Sharia Pawnshop has not fully correspond to some Figh Fatwa and Economic Islam Principles, that the clarity of the goods at the contract, which contains the value of speculative investments.

Keywords: Gold Investment, Buy Pawn, Islamic / Sharia Pawnshop,.

\section{PENDAHULUAN}

Sebagai suatu sistem hidup (millah, din) ajaran Islam dapat diklasifikasikan menjadi dua bagian. Pertama, yang berhubungan dengan ibadah khususnya yang mengandung hubungan dimensi vertikal. Sedangkan yang kedua, yang berhubungan dengan permasalahan hubungan antar sesama mahluk (muamalat). Kedua sub-sistem ini tidak dapat dipisahkan satu sama lain. Karena keduanya merupakan komplementer satu dengan yang lainnya. Jika keduanya dipisahkan maka manusia akan mendapatkan kehinaan.

Memahami sistem ekonomi Islam secara utuh dan komprehensif, selain memerlukan pemahaman tentang Islam juga memerlukan pemahaman yang memadai tentang pengetahuan ekonomi umum mutakhir. Keterbatasan dalam pemahaman Islam akan berakibat pada tidak dipahaminya sistem ekonomi Islam secara utuh dan menyeluruh, mulai dari aspek fundamental ideologis sampai pemahaman konsep serta aplikasi praktisnya. Akibatnya, tidak jarang pemahaman yang muncul, hanya menganggap bahwa sistem ekonomi Islam tidak berbeda dengan sistem ekonomi umum yang selama ini ada, hanya minus sistem ribawi (riba) ditambah dengan zis (zakat, infak, sedekah) juga disertai adanya prinsip-prinsip akhlak yang diperlukan dalam kegiatan ekonomi. Sebaliknya keterbatasan dalam pemahaman tentang ekonomi umum mutakhir akan berakibat pada anggapan bahwa sistem ekonomi Islam tidak memiliki konsep operasional, namun hanya memiliki konsep-konsep teoritis dan moral seperti yang terdapat pada hukum-hukum fikih tentang muamalah, seperti perdagangan, sewa menyewa, sistem simpan pinjam dan lain-lain. Dengan kata lain menurut mereka system Islam hanya berisi tentang konsep-konsep dan garis besarnya saja, tetapi sesungguhnya pemahaman Islam diperlukan untuk memahami prinsipprinsip ekonomi Islam secara utuh, yang memerlukan bagian dari sistem keseluruhan. Atau dengan kata lain agar falsafah, tujuan, dan strategi operasional dari sistem ekonomi Islam dapat dipahami secara komprehensip. Dengan demikian tidak ada lagi anggapan bahwa sistem ekonomi Islam tidak memiliki landasan filosofis, politis maupun strategis. Yang perlu digarisbawahi disini bahwa perbedaan mendasar antara kajian ekonomi Islam dengan ekonomi kontemporer lainnya

Al Qalam: Jurnal Ilmiah Keagamaan dan Kemasyarakatan Vol. 16, No. 2

Maret - April 2022 
S. Purnamasari, Kurniaty, Purnama Rozak : Operasional Produk Investasi Emas Pada Pegadaian Syariah Ditinjau Dari Prinsip Ekonomi Islam

adalah, prinsip-prinsip, dan kaidah-kaidah hukum yang menyertainya. Jelaslah bahwa ekonomi Islam yang berlandaskan etika ini tidak hanya secara harfiah melarang sesuatu itu hanya untuk sesuatu yang sesaat dan kepentingan yang sesaat juga, tetapi lebih umum dan menyeluruh untuk kepentingan dan kemaslahatan manusia seluruhnya baik dalam kehidupan di dunia dan di akhirat.

Islam merupakan agama yang tidak memarginalkan dan tidak mengeksklusifkan satu golongan karena Islam adalah agama bagi seluruh alam yang mengatur seluruh perkara dengan peraturannya yang jelas, tidak terkecuali masalah mu'amalah untuk mencapai fala $^{4}$ dan Islam juga agama rahmatan lil- 'lamin yang berarti agama Islam berfungsi untuk memberikan keamanan kenyamanan bagi seluruh makhluk. Perkara halal dan haram menjadi mercusuar pertimbangan dari setiap transaksi.

Akan tetapi hal itu berubah tatkala sistem Ekonomi Islam tiada, umat muslim dipaksa harus mengikuti konsep kapitalisme, ${ }^{5}$ yang memang tidak mengenal kata halal dan haram. Ini karena akar sistem kapitalisme adalah paham sekulerisme, ${ }^{6}$ yang pada akhirnya kaum muslim hidup dari sistem Ekonomi yang jauh dari nilai keislaman, termasuk pegadaian syariah. ${ }^{7}$

Eksistensi lembaga keuangan yang menawarkan berbagai bentuk fasilitas pembiayaan untuk lebih memperluas penyediaan pembiayaan alternative bagi dunia usaha dalam sistem perekonomian modern sangatlah dibutuhkan. Lembaga pembiayaan diperlukan guna mendukung dan memperkuat sistem keuangan nasional yang terdiversifikasi sehingga dapat memberikan alternatif yang lebih banyak bagi pengembangan sektor usaha, tak terkecuali pegadaian. Bahkan maraknya investasi emas akhir akhir ini, membuat lembaga keuangan semakin berlomba-lomba memantapkan diri dengan berinovasi dalam produk unggulan lain berbasis emas, tak terkecuali pegadaian syariah. Saat ini pegadaian syariah sendiri telah mengembangkan beberapa inovasi dan kreatifitas dalam beberapa produk unggulan. Inovasi dan kreatifitas ini kiranya menjadi suatu hal yang lazim adanya mengingat semakin berkembangnya zaman dan kecantikan dunia dengan teknologinya, akan tetapi perlu diingat bahwa inovasi dan kreatifitas tidak boleh melanggar dari nilai-nilai dasar Ekonomi Islam. ${ }^{8}$

\footnotetext{
${ }^{4}$ Dalam pengertian literal, falah adalah kemuliaan dan kemenangan yaitu kemuliaan dan kemenangan dalam hidup baik dunia maupun akhirat. lihat Munrokhim Misanam, et.al., (2008), Ekonomi Islam, (Jakarta: PT Raja Grafindo Persada), h. 525 .

${ }^{5}$ Kapitalisme adalah sistem ekonomi dimana kepemilikan perorangan atas kekayaan diakui. Sumaji, et.al. (2006), Kamus Ekonomi,(ttp: wipress, 2006), Hal. 137.

${ }^{6}$ Kamus Besar Bahasa Indonesia, h.1287

${ }^{7}$ Nur Chamid, (2010), Jejak Langkah Sejarah Pemikiran Ekonomi Islam, (Yogyakarta: Pustaka Pelajar).

${ }^{8}$ Munrokhim Misanam, Ekonomi Islam, hh. 58-65.
}

Al Qalam: Jurnal Ilmiah Keagamaan dan Kemasyarakatan Vol. 16, No. 2

Maret - April 2022 
S. Purnamasari, Kurniaty, Purnama Rozak : Operasional Produk Investasi Emas Pada Pegadaian Syariah Ditinjau Dari Prinsip Ekonomi Islam

Adapun salah satu hasil dari kreatifitas dan inovasi produk pegadaian syariah yaitu produk investasi emas. Investasi Emas di Pegadaian Syariah / MULIA ( Murabahah Logam Mulia untuk Investasi Abadi ) dilakukan dengan tunai maupun angsuran. Jika nasabah/investor membutuhkan dana, emas tersebut bisa dijual atau digadaikan kembali ke pegadaian.

Dari latarbelakang diatas, penulis akan melakukan penelitian yaitu analisis prinsip-prinsip ekonomi islam terhadap produk investasi emas di Pegadaian Syariah Cabang Kebun Bunga Banjarmasin.

\section{LANDASAN TEORI}

\section{Prinsip-prinsip Ekonomi Islam dalam Investasi}

Prinsip-prinsip Islam dalam muamalah yang harus diperhatikan oleh pelaku investasi syariah (pihak terkait) adalah:

a. Tidak mencari rizki pada hal yang haram, baik dari segi dzatnya maupun cara mendapatkanya serta tidak menggunakannya untuk hal-hal yang haram.

b. Tidak mendzalimi dan tidak didzalimi.

c. Keadilan pendistribusian kemakmuran.

d. Transaksi dilakukan atas dasar rida sama rida.

e. Tidak ada unsur riba, maysir dan gharar

Berdasarkan keterangan diatas, maka kegiatan investasi mengacu pada prinsip ekonomi islam yang berlaku. Perputaran modal pada kegiatan ini tidak boleh disalurkan kepada jenis industri yang melakukan kegiatan-kegiatan yang diharamkan. Pembelian saham misalnya atas saham pabrik minuman keras, pembangunan penginapan untuk prostitusi dan lainnya yang bertentangan dengan syariah berarti diharamkan. ${ }^{9}$ Semua transaksi yang terjadi pada konsep ini harus atas dasar suka sama suka, tidak ada unsur pemaksaan, tidak ada pihak yang didzalimi atau mendzalimi. Seperti goreng-menggoreng saham pada pasar modal. Tidak ada unsur riba, tidak bersifat spekulasi atau judi, dan semua transaksi harus transparan dan diharamkan adanya insider trading. ${ }^{10}$

\footnotetext{
${ }^{9}$ Inggrid Tan, Bisnis dan Investasi Sistem Syariah, (Yogyakarta: Universitas Atma Jaya Yogyakarta, 2019), hh. 15-16.

${ }^{10}$ Insider Trading (perdagangan orang dalam) adalah perdagangan yang menggunakan informasi orang dalam yaitu informasi-informasi yang tidak diketahui oleh umum untuk mendapatkan suatu keuntungan dalam perdagangan aktiva. Melakukan perdagangan tersebut dianggap sebagai tindakan ilegal. Sumadji, Kamus, h. 387.
}

Al Qalam: Jurnal Ilmiah Keagamaan dan Kemasyarakatan Vol. 16, No. 2

Maret - April 2022 
S. Purnamasari, Kurniaty, Purnama Rozak : Operasional Produk Investasi Emas Pada Pegadaian Syariah Ditinjau Dari Prinsip Ekonomi Islam

\section{Beli Gadai}

Produk "beli gadai" pada dasarnya adalah bentuk dukungan atas praktek formula kebun emas. Skema beli gadai emas secara sederhana dapat dijelaskan sebagai berikut: Emas dibeli di Outlet Pegadaian Syariah kemudian emas tersebut digadaiakan di Pegadaian tersebut, nasabah dapat pembiayaan lalu beli emas lagi dan digadaikan dan seterusnya. Adapaun dengan beli angsuran maka investor/nasabah menyiapkan dana untuk biaya administrasi, dan menyiapkan Down Payment atau uang muka, setelah emas tersebut lunas kemudian digadaikan dan seterusnya berulang kali. Keuntungannya, nasabah dapat melunasi emas dalam jangka waktu tertentu, tanpa terpengaruh kenaikan harga emas. Dan keuntungan yang bersifat investatif, sekalipun emas itu tidak bertujuan untuk dimiliki oleh nasabah, nasabah dapat memperoleh keuntungan atas kenaikan harga emas dikurangi ujrah atau biaya titip atas emas yang digadai. ${ }^{11}$

\section{Investasi Logam Mulia}

Investasi Logam Mulia / MULIA (murabahah logam mulia untuk investasi abadi anda) adalah jenis pembiayaan yang memfasilitasi kepemilikan emas batangan melalui penjualan logam Mulia oleh Pegadaian kepada masyarakat secara tunai dan atau dengan pola angsuran dengan proses cepat dalam jangka waktu tertentu yang fleksibel. Akad MULIA adalah persetujuan atau kesepakatan yang dibuat bersama antara Pegadaian dan Nasabah atas sejumlah pembelian Logam Mulia disertai keuntungan dan biaya-biaya yang disepakati. Logam mulia yang paling dikenal didunia adalah emas dan perak. Kelebihan logam mulia dibandingkan produk investasi lain adalah: pertama nilainya cenderung naik setiap tahun (berkisar 20\%), dan kedua likuid, dalam arti mudah dijual atau dicairkan. Dalam satu tahun terakhir, harga emas naik lebih dari $25 \%$. Sementara dalam 10 tahun terakhir, harga emas melesat sekitar $40 \%$.

\section{Tujuan Investasi Emas}

Sesuai dengan Fatwa Dewan Syariah Nasional Majelis Ulama Indonesia No: 6/DSNMUI/III/2002 tentang Rahn Emas, pada ketentuan umum Rahn Emas ini dijelaskan tujuan Investasi emas bahwa masyarakat pada umumnya telah lazim menjadikan emas sebagai barang berharga yang disimpan dan menjadikannya objek Rahn sebagai jaminan utang untuk mendapatkan pinjaman uang. Dari sini bisa dipahami yakni emas dijadikan barang berharga yang layak untuk disimpan dan bukan lagi menjadi rahasia umum atas legalitas emas sebagai barang berharga dan layak untuk menjadi acuan investasi alternatif di zaman modern. Adapun maksud

${ }^{11}$ Haikal, Panduan, hh. 85-86.

Al Qalam: Jurnal Ilmiah Keagamaan dan Kemasyarakatan Vol. 16, No. 2

Maret - April 2022 
S. Purnamasari, Kurniaty, Purnama Rozak : Operasional Produk Investasi Emas Pada Pegadaian Syariah Ditinjau Dari Prinsip Ekonomi Islam

emas menjaga nilai adalah emas dijadikan acuan dimasa mendatang, jadi jika dikaitkan dengan investasi emas menjaga nilai adalah pola investasi yang ditujukan untuk menjaga nilai uang.

\section{METODE PENELITIAN}

\section{A. Jenis Penelitian}

Penelitian ini adalah penelitian lapangan, dimana masalah yang diajukan di dalamnya ditentukan pada masalah operasional. Jenis penelitian ini adalah penelitian kualitatif. Berdasarkan rangkaian teori tentang penelitian kualitatif tersebut, peneliti berkeyakinan untuk menggunakan metode penelitian deskripif, karena pada penelitian ini memusatkan pada deskripsi data yang berupa kalimat-kalimat yang mendalam, yang berasal dari informan dan prilaku berbagai hal yang ada relevansinya dengan aplikasi skim beli gadai menurut prinsip ekonomi Islam.

\section{B. Sifat Penelitian}

Penelitian yang dilakukan bersifat evaluation research, yang menganalisa dan menyajikan fakta secara sistemik sehingga dapat lebih mudah untuk difahami dan disimpulkan berdasarkan pedoman yang berlaku. Kesimpulan yang diberikan selalu jelas dasar faktanya sehingga semuanya selalu dapat dikembalikan langsung kepada data yang diperoleh. Penelitian ini dilakukan untuk mengetahui keadaan sebenarnya yang ada sekarang.

\section{Lokasi Penelitian}

Penelitian ini mengangkat studi kasus tentang operasional produk investasi emas pada Pegadaian Syariah. Adapun alasan dipilihnya pegadaian syariah karena pada saat awal penelitian penulis mengetahui bahwa pegadaian syariah telah memiliki produk yang menjadi pusat penelitian yang dilakukan penulis.

\section{Sumber Data}

Ada dua jenis data yang digunakan yakni data primer dan sekunder. Dalam penelitian ini data primer diperoleh langsung dari lokasi penelitian atau disebut juga data lapangan, dalam hal ini Pegadaian Syariah. Sedangkan data sekunder adalah data yang diperoleh tidak secara langsung dari objek penelitian tetapi dari pihak lain yang mempunyai informasi data yang diperlukan atau literatur yang berhubungan dengan obyek penelitian. Hal ini penulis lakukan dengan membaca, mempelajari buku-buku yang memiliki korelasi dengan penelitian kali ini.

Al Qalam: Jurnal Ilmiah Keagamaan dan Kemasyarakatan Vol. 16, No. 2

Maret - April 2022 
S. Purnamasari, Kurniaty, Purnama Rozak : Operasional Produk Investasi Emas Pada Pegadaian Syariah Ditinjau Dari Prinsip Ekonomi Islam

\section{E. Teknik Pengumpulan Data}

\section{Wawancara}

Model wawancara ini adalah dengan mengajukan pertanyaan secara terstruktur dan tetap mengacu pada materi penelitian atau pokok masalah tertentu.

\section{Studi Kepustakaan (library research)}

Dalam hal ini peneliti menggali teori yang telah berkembang dalam bidang ilmu yang berhubungan dengan obyek penelitian. Mencari metode serta teknik penelitian baik dalam pengumpulan data maupun dalam menganalisis data yang telah dibahas sebelumnya. Untuk memperoleh orientasi yang lebih luas dalam permasalahan yang dipilih serta menghindari duplikasi-duplikasi yang tidak diinginkan.

\section{Observasi/Pengamatan}

Observasi ini dilakukan untuk mencari data yang berhubungan dengan hasil-hasil dilapangan. Teknik ini biasanya disebut observasi partisipasi pasif yang dilakukan secara formal dan informal untuk mengamati pokok permasalahan yang diteliti.

\section{Dokumentasi}

Dokumen merupakan catatan peristiwa yang sudah berlalu. Dokumen dapat berupa tulisan, gambar atau karya-karya monumental seseorang. Didalam melaksanakan metode dokumentasi, penulis meneliti benda-benda tertulis seperti notulen, catatan, surat kabar, buku, kwitansi dan lain-lain yang dianggap penting dalam penelitian.

\section{F. Teknik Analisis Data}

Data yang diperoleh dalam penelitian ini berupa data primer dan data sekunder disajikan dalam uraian yang sesuai dengan hasil penelitian, kemudian disusun secara teratur. Data yang disajikan mula-mula dalam bentuk gambaran, kemudian dianalisis dan berakhir dengan penarikan kesimpulan. Dalam analisis data yakni data yang diperoleh dari hasil penelitian, baik data dari hasil wawancara, library research, observasi maupun dari telaah dokumen, disusun secara sistematis, kemudian dianalisis dengan menggunakan metode:

\section{Analisis Kualitatif}

Analisis kualitatif yaitu penganalisisan data sekunder, pertama-tama dilakukan inventarisasi terhadap norma atau prinsip-prinsip terkait dengan perbankan syariah. Dalam hal ini dikumpulkan asas-asas terkait permasalahanya yaitu tentang operasional produk investasi emas untuk kemudian diorganisir kedalam suatu sistem yang komprehensif.

Al Qalam: Jurnal Ilmiah Keagamaan dan Kemasyarakatan Vol. 16, No. 2

Maret - April 2022 
S. Purnamasari, Kurniaty, Purnama Rozak : Operasional Produk Investasi Emas Pada Pegadaian Syariah Ditinjau Dari Prinsip Ekonomi Islam

\section{Analisis Deskriptif}

Analisis deskriptif yaitu penganalisaan data primer secara mendalam dengan menghubungkan pada data sekunder sehingga diperoleh gambaran secara jelas dan rinci fenomena yang menjadi pokok bahasan tanpa melakukan perhitungan secara statistik.

\section{ANALISIS DAN PEMBAHASAN}

Pada penelitian ini penulis melakukan analisis apakah prosedur pelalaksanaan investasi emas di pegadaian syariah Cabang Kebun Bunga Banjarmasin, dengan menggunakan skim beli gadai telah sesuai dengan pandangan ekonomi Islam atau figh dan Fatwa Dewan Syariah Nasional terkait transaksi ini. Analisis ini difokuskan pada tujuan investasi emas, mekanisme, jangka waktu investasi emas dan keuntungan investasi emas. Dalam prakteknya pegadaian telah memiliki kerjasama dengan beberapa toko emas di sekitar, dengan adanya kerjasama ini dapat mempermudah kinerja antara pegadaian dengan nasabah yang menginginkan emas.

\section{A. Tujuan Investasi Emas}

Transaksi investasi emas ini memiliki beberapa tujuan khusus yakni diantaranya adalah untuk menjaga nilai serta tujuan investasi jangka pendek. Jika merujuk kepada kegunaan emas sendiri, tidak salah jika komoditi ini dijadikan suatu barang simpanan, tentunya dengan alasan bahwa emas mudah disimpan dan tergolong barang liquid yang dengan mudah dapat dicairkan sewaktu-waktu.

Hal ini sesuai dengan Fatwa Dewan Syariah Nasional Majelis Ulama Indonesia No: 26/DSN-MUI/III/2002 tentang Rahn Emas, pada ketentuan umum Rahn Emas ini dijelaskan tujuan Investasi emas bahwa masyarakat pada umumnya telah lazim menjadikan emas sebagai barang berharga yang disimpan dan menjadikannya objek Rahn sebagai jaminan utang untuk mendapatkan pinjaman uang. Dari sini bisa dipahami yakni emas dijadikan barang berharga yang layak untuk disimpan dan bukan lagi menjadi rahasia umum atas legalitas emas sebagai barang berharga dan layak untuk menjadi acuan investasi alternatif di zaman modern.

Adapun maksud emas menjaga nilai adalah emas dijadikan acuan dimasa mendatang, jadi jika dikaitkan dengan investasi emas menjaga nilai adalah pola investasi yang ditujukan untuk menjaga nilai uang. Sebagai contoh_Pak Rozaq mempunyai uang Rp2 juta, kemudian membeli emas, beberapa tahun kemudian nilai emas akan naik seiring dengan terus naiknya inflasi mata uang. Jadi, dengan emas setidaknya nilai uang pak budi yang sebesar Rp2 juta itu akan sama dengan nilai mata uang di masa mendatang beberapa tahun kemudian. Sedangkan investasi emas jangka pendek di pegadaian bisa dipahami sebagai pola investasi emas dengan membeli emas

Al Qalam: Jurnal Ilmiah Keagamaan dan Kemasyarakatan Vol. 16, No. 2

Maret - April 2022 
S. Purnamasari, Kurniaty, Purnama Rozak : Operasional Produk Investasi Emas Pada Pegadaian Syariah Ditinjau Dari Prinsip Ekonomi Islam

pada saat harga murah dan menjualnya pada saat harga emas mahal. Seorang nasabah yang melakukan investasi emas jangka pendek akan mendapatkan keuntungan dengan adanya selisih harga beli dan harga jual atau dikenal dengan istilah profit margin. Kiranya tujuan investasi JAPEN ini menjadi perhatian khusus bagi pegadaian syariah yang menggunakan transaksi investasi emas, disamping emas sendiri merupakan tergolong barang ribawi. Kiranya hal ini sesuai dengan larangan Allah SWT dalam Al-Quran yang berbunyi:

Artinya: hai orang-orang yang beriman, sesungguhnya minuman khamar, berjudi, (berkorban untuk) berhala, mengundi nasib dengan panah, adalah termasuk perbuatan syaitan. Maka jauhilah perbuatan tersebut agar kamu mendapatkan keberuntungan. ${ }^{12}$

Ayat diatas menunjukkan haramnya perbuatan maysir dan qimar dalam mu'amalah. Maysir adalah setiap mu'amalah yang masuk kedalamnya setelah mengeluarkan biaya dengan dua kemungkinan yakni untung dan rugi. Sedangkan qimar menurut sebagian ulama adalah sama dengan maysir, dan menurut kesepakatan ulama lainya bahwa qimar hanya pada mu'amalah yang berbentuk perlombaan dan pertaruhan.

\section{B. Mekanisme Investasi Emas}

Proses investasi emas Pegadain Syariah Cabang Kebun Bunga Banjarmasin berlangsung mudah dan cepat, hal ini diakui oleh seorang investor/nasabah yang pernah mengajukan investasi emas bahwa prosesnya lebih cepat dan biaya gadai lebih murah dibandingkan perum pegadaian. Adapun mekanisme investasi emas dengan Skim Beli Gadai secara sederhana dapat dijelaskan sebagai berikut: Nasabah mengajukan keinginan untuk investasi emas, pegadaian syariah mendampingi nasabah dalam proses investasi emas, Melalui mekanisme gadai di pegadaian syariah emas dibeli secara tunai atau angsur kemudian emas tersebut digadaikan di pegadaian tersebut. Maka dapat dipahami dengan adanya jaminan ini kecil kemungkinan akan adanya sengketa dari investasi emas. Jika terjadi sengketa maka emas yang digadaikan bisa diliquidkan atau dijual, termasuk pada saat nasabah membutuhkan dana secara mendadak.

Menjual belikan emas secara kredit hukum haram. Karena emas termasuk salah satu barang ribawi. Dalam pandangan Islam, emas termasuk salah satu barang ribawi yang jika dijual belikan harus dilakukan secara kontan (yadan bi yadin). Yaitu tidak boleh bertempo (nasi'ah) atau secara kredit. Dalil keharaman adalah sebagaimana hadist Nabi Muhammad yang diriwayatkan dari Ubadah bin Shamit, yang artinya: "Emas ditukarkan dengan emas, perak dengan perak, gandum dengan gandum, jewawut dengan jewawut, kurma dengan kurma, garam

${ }^{12}$ QS Al-Maidah (5): 90.

Al Qalam: Jurnal Ilmiah Keagamaan dan Kemasyarakatan Vol. 16, No. 2

Maret - April 2022 
S. Purnamasari, Kurniaty, Purnama Rozak : Operasional Produk Investasi Emas Pada Pegadaian Syariah Ditinjau Dari Prinsip Ekonomi Islam

dengan garam, harus sama takarannya dan harus dilakukan dengan kontan (yadan bi yadin). Dan jika berbeda jenis-jenisnya, maka juallah sesukamu asalkan dilakukan dengan kontan". (Hadist Riwayat Imam Muslim). Dan Riwayat dari Ubadah bin Shamit, bahwa Nabi bersabda : "Jualah emas dengan perak sesukamu, asalkan dilakukan dengan kontan". (HR Tirmidzi).

Sementara Imam Syaukani dalam karyanya Nailul Authar, menjelaskan bahwa dengan hadis tersebut, jelas bahwa tidak boleh menjual suatu barang ribawi dengan sesama barang ribawi lainnya, kecuali secara kontan. Tidak boleh pula menjualnya secara bertempo (kredit), meskipun keduanya berbeda jenis dan ukurannya, misalnya menjual gandum dan jewawut (sya'ir), dengan emas dan perak."

Adapun Imam Taqiyuddin an-Nabhani saat menjelaskan hadist berikut: "Juallah emas dengan perak sesukamu, asalkan dilakukan dengan kontan". (HR Tirmidzi). Ia menjelaskan bahwa Nabi telah melarang menjual emas dengan mata uang perak secara utang (kredit).

Adanya dalil-dalil di atas jelas menunjukkan bahwa memperjualbelikan emas haruslah memenuhi syaratnya, dimana sarat utamanya adalah harus kontan. Hal inilah yang yang oleh para Ulama Fiqih Isalam disebut dengan "taqabudh" (serah terima dalam majelis akad) berdasarkan bunyi nash "yadan bi yadin" (dari tangan ke tangan). Dengan demikian, menjualbelikan emas secara kredit atau angsuran, melanggar persyaratan tersebut sehingga hukumnya secara syar'i adalah haram.

\section{Jangka Waktu Investasi Emas}

Jangka waktu investasi emas adalah 4 bulan, karena investasi ini merupakan investasi jangka pendek, tetapi tidak menutup kemungkinan untuk diperpanjang setelah masa kontrak selesai. Investasi ini hak sepenuhnya dimiliki oleh nasabah, baik ia ingin memiliki, investasi jangka pendek saja dan termasuk masalah waktu investasi emas juga. Pihak pegadaian syariah tidak memiliki wewenang untuk mempengaruhi nasabah mengenai jangka waktu Investasi emas ini, termasuk didalamnya waktu yang tepat melempar emas yang telah dibeli untuk dijual ke toko emas. Jadi investasi emas ini berjangka waktu 4 bulan, dan nasabah memiliki hak untuk memperpanjang atau menyelesaikan sebelum waktu yang telah ditentukan.

\section{Keuntungan Investasi Emas}

Adapun keuntungan dari investasi emas ini adalah adanya perbedaan harga atau kenaikan harga emas, yakni adanya perbedaaan atau kenaikan antara harga beli dengan harga jual emas itu sendiri. Contoh dalam 2 sampai 10 hari saja apabila sudah terjadi kenaikan harga emas maka pasti akan mendapatkan keuntungan. Inilah yang menjadi keuntungan investasi dengan emas, dengan harga yang selalu naik dari hari-hari sebelumnya. Di samping itu emas berguna untuk menjaga

Al Qalam: Jurnal Ilmiah Keagamaan dan Kemasyarakatan Vol. 16, No. 2

Maret - April 2022 
S. Purnamasari, Kurniaty, Purnama Rozak : Operasional Produk Investasi Emas Pada Pegadaian Syariah Ditinjau Dari Prinsip Ekonomi Islam

nilai agar tidak merosot terkena inflasi. Adapun keuntungan bagi bank sendiri adalah adanya biaya atau ujrah atas emas yang digadaikan dan disimpan di bank syariah. Jika kita meninjau ulang terhadap pola keuntungan dari investasi emas dimana keuntungan investasi ini berupa jangka pendek yakni adanya selisih antara harga beli dengan harga jual. Disini ada keleluasaan nasabah untuk menggoreng harga emas, kapan nasabah membeli emas dan kapan nasabah menjualnya. Dengan ini kiranya jelas pola investasi emas ini bermain pada ranah spekulatif, karena hanya dengan keuntungan yang diperoleh dari selisih harga beli dengan harga jual lah nasabah mendapatkan keuntungan dengan sendirinya. Begitu pula jika saat emas dinanti kenaikannya, sedangkan harga emas semakin lesu maka mau tidak mau, nasabah tetap menggadaikan emasnya di perbankan sampai harga emas menjulang tinggi, kecuali pada saat-saat tertentu yang mengharuskan nasabah untuk menjual

emas yang digadaikannya.

Konsep seperti diatas lebih dikenal dengan sebutan spekulatif atau maysir, yang secara umum menggambarkan adanya keuntungan tanpa adanya usaha riil untuk mendapatkan keuntungan tersebut. Memang pada hakikatnya pola investasi adalah suatu pola bisnis yang ingin mendapatkan keuntungan di masa yang akan datang. Tidak salah jika investasi lebih menginginkan adanya keuntungan di masa depan, tetapi tentunya kesemuanya ini diiringi dengan usaha riil yang jelas, bukan hanya mengharapkan adanya kenaikan dari harga emas. Dalam prinsip ekonomi islam berkenaan dengan konsep investasi emas yakni tidak adanya larangan berupa pola investasi emas apabila hal itu tetap mengacu pada prinsip islam. Tetapi jika hal itu telah melampaui batasan yang diberikan oleh prinsip islam, maka hal itu harus ditinggalkan. Adapun unsur-unsur yang dilarang dalam transaksi diantaranya: perniagaan barang-barang yang haram, bunga/riba, perjudian atau spekulasi yang disengaja dan ketidaksejalsan serta manipulatif (gharar). Dengan adanya batasan dalam prinsip ekonomi islam diatas kiranya jelas sekali pola investasi yang mengandung unsur spekulatif merupakan sesuatu yang dilarang dalam islam. Dalam basic kebijakan ekonomi islam pun dijelaskan secara tegas akan larangan riba, pelarangan gharar, barang-barang yang haram dan pentingnya pelembagaan zakat dalam kebijakan yang diberikan oleh ekonomi islam.

Jika menilik sejenak tentang konsep maqasid syariah berkenaan dengan konsep investasi yang spekulatif akan menyebabkan adanya ketidakadilan, yang mana akan terjadinya gap atau kesenjangan pihak investasi spekulatif dengan para pekerja sektor riil. Hal ini jelas mengakibatkan ketidakadilan dimana seorang investor dengan mudahnya memperoleh uang sedangkan pihak yang semangat bekerja hanya mendapatkan uang yang kurang sepadan dengan

Al Qalam: Jurnal Ilmiah Keagamaan dan Kemasyarakatan Vol. 16, No. 2

Maret - April 2022 
S. Purnamasari, Kurniaty, Purnama Rozak : Operasional Produk Investasi Emas Pada Pegadaian Syariah Ditinjau Dari Prinsip Ekonomi Islam

apa yang dilakukan. Jika melihat lebih dalam lagi dari nilai-nilai dasar ekonomi islam yang terdapat konsep adil dalam formulasi nilai-nilai dasar ekonomi islam. Adapun keadilan yang dimaksud disini berupa nilai turunan yang berasal darinya salah satunya adalah persamaan kompensasi. Persamaan kompensasi adalah pengertian adil yang paling umum, yaitu bahwa seseorang harus memberikan kompensasi yang sepadan kepada pihak lain sesuai dengan pengorbanan yang dilakukan. Pengorbanan yang telah dilakukan inilah yang menimbulkan hak pada seseorang yang telah melakukan pengorbanan untuk memperoleh balasan yang seimbang dengan pengorbanannya. ${ }^{13}$

\section{SIMPULAN}

Dari hasil penelitian dan analisis data yang dilakukan penulis terhadap aplikasi Investasi Emas Pada Pegadaian Syariah Cabang Kebun Bunga Banjarmasi, dapat diambil kesimpulan yang merupakan jawaban dari permasalahan dalam penelitian ini, yaitu:

1. Oprasional produk Investasi Emas merupakan suatu investasi yang bisa dilakukan oleh pihak manapun/ siapapun, dengan mekanisme nasabah mengajukan keinginan kepada pegadaian syariah dengan cara tunai ataupun angsuran. Bentuk investasi emas ini memanfaatkan sistem gadai emas syariah dan skim beli gadai. Secara garis besar cara investasi kebun emas adalah dengan menyediakan sejumlah uang untuk membeli sejumlah emas, lalu emas tersebut digadaikan selama jangka waktu tertentu, uang hasil gadai ditambahkan lagi untuk membeli emas dengan berat yang sama seperti pembelian pertama, kemudian digadaikan lagi, begitu seterusnya sampai beberapa kali sepanjang dipandang telah cukup.

2. Secara umum aplikasi Investasi Emas merujuk kepada prinsip Ekonomi Islam yang mana masih terdapat beberapa ketidaksyariahan dari akad Investasi emas, diantaranya adalah gharar atau ketidakjelasan emas saat transaksi, maysir atau spekulasi berupa selisih harga beli dengan harga jual yang tidak diketahui yang dilakukan oleh pihak nasabah, dan mekanisme investasi emas dengan cara angsuran.

\section{DAFTAR PUSTAKA}

Ali Zainudin, Hukum Gadai Syariah, Jakarta: Sinar Grafika, 2018.

Al Jawi, Shiddiq, Hukum Jual Beli Emas Secara Kredit, http://konsultasi.wordpress.com/2010/05/20/hukum-jual-beli-emas-secara kredit/

${ }^{13}$ Munrokhim Misanam, et.al., (2018), h. 59.

Al Qalam: Jurnal Ilmiah Keagamaan dan Kemasyarakatan Vol. 16, No. 2

Maret - April 2022 
S. Purnamasari, Kurniaty, Purnama Rozak : Operasional Produk Investasi Emas Pada Pegadaian Syariah Ditinjau Dari Prinsip Ekonomi Islam

Al-Quran Karim dan Terjemahan, Yogyakarta: UII Press, 2019.

An Nabhani, Taqiyuddin, Nidzam Al Iqtishadi, diterjemahkan oleh Hafidz Abd., Sistem Ekonomi Islam, Jakarta: Hizbut Tahrir Indonesia, 2010

Chamid Nur, Jejak Langkah Sejarah Pemikiran Ekonomi Islam, Yogyakarta: Pustaka Pelajar, 2015.

Hafidz Abdurrahman. "Bisnis \& Muamalah Kontemporer, Al Azhar Freshzone Publishing, Bogor, 2017

Haikal Tanti, Panduan Cerdas \& Syar'i Investasi Syariah Dinar-Emas-Sukuk- Reksa Dana. Yogyakarta: Araska, 2016.

Kasmir, Bank Dan Lembaga Keuangan Lainnya, ,Jakarta: PT Raja Grafindo Persada, 2012.

Majalah Sharing, Investasi Emas, Edisi 38, Tahun IV Februari 2010.

Mujahidin Ahmad, Prosedur Penyelesaian Sengketa Ekonomi Syariah di Indonesia, Bogor: Ghalia Indonesia, 2010

Munrokhim Misanam, dkk, Ekonomi Islam. Jakarta: PT Raja Grafindo Persada, 2018.

Rais,Sasli, Pegadaian Syariah, Jakarta: Universitas Indonesia, 2018.

TanInggrid, Bisnis dan Investasi Sistem Syariah, Yogyakarta.: Universitas Atma Jaya Yogyakarta , 2009

Wiku Suryomurti, supercardas investasi syariah,Agung-Cet.1, Jakarta: Qultum media, 2011.

Al Qalam: Jurnal Ilmiah Keagamaan dan Kemasyarakatan Vol. 16, No. 2

Maret - April 2022 